\title{
Ewa Łaźniewska
}

Uniwersytet Ekonomiczny w Poznaniu

Katedra Polityki Koniunktury i Polityki Gospodarczej

Ewa.Lazniewska@ue.poznan.pl

\section{Istota koncepcji smart city. Aktywność miasta Poznania na drodze do smart city ${ }^{1}$}

\begin{abstract}
Zarys treści: Dyskusja $\mathrm{w}$ zakresie podejścia do definiowania inteligentnego miasta jest w literaturze ciągle aktualna (Moustaka i in. 2018, de Falco i in. 2019). Autorzy bardzo różnorodnie określają ramy koncepcji. Jednym z czynników, który ma wpływ na tę różnorodność podejść, jest kwestia ciągle przyspieszającego rozwoju nowych technologii, przez co koncepcja ma charakter ewolucyjny (Mora, Deakin 2019). Innym ważnym czynnikiem oddziałującym na różne podejścia do definiowania problemu jest cała gama możliwości zindywidualizowania definicji w odniesieniu do wybranego przypadku miasta, co jest konieczne, bo miasta różnią się od siebie nie tylko problemami, ale możliwościami technologicznymi ich rozwiązywania. Samorządy starają się stworzyć własne rozwiązania, które często powstają jako połączenie tzw. dobrych praktyk, uważanych za wzorcowe w Europie, np. przypadki Wiednia czy Barcelony (Mora i in. 2019) oraz własnych wizji rozwojowych. Nie wszystkie miasta w jednakowym stopniu są przygotowane do przyjęcia rozwiązań charakterystycznych dla smart city. Ten problem został zbadany przez autorkę, a wyniki ankiet przedstawione w empirycznej części artykułu na przykładzie miasta Poznania. Różnorodne czynniki wpływają na dużą dynamikę w formułowaniu koncepcji, co powoduje, że jest to niezmiernie intersujące pole badawcze. Celem artykułu jest próba syntezy różnych podejść do definiowania inteligentnego miasta oraz wskazanie na ich wspólne cechy. Z kolei celem założonym w części empirycznej jest pokazanie stanu gotowości miasta Poznania do przyjęcia rozwiązań typu smart city. Podstawową tezą artykułu jest stwierdzenie, że koncepcja smart city jest silnie związana z postępem technologicznym i w miarę rozwoju technologii pojawiają się nowe obszary aktywności miasta, które mogą być przez nią wdrażane. Pojęcie miasta inteligentnego może być różnorodnie definiowane, ponieważ każdy ekosystem ma swoją specyfikę i możliwości wsparcia rozwoju w zakresie transportu ludzi i towarów, przeciwdziałania smogowi, przeciwdziałania zmianom klimatycznym i innych rozwiązań z obszaru np. turystyki.
\end{abstract}

Słowa kluczowe: smart city, rozwój miasta, inteligentne technologie, samorząd, smart collaboration, Poznań

1 Artykuł powstał w części empirycznej w oparciu o materiały przekazane przez Rafała Ratajczaka z Wielkopolskiego Centrum Wspierania Inwestycji sp. z. o. o., Michała Łakomskiego, pełnomocnika prezydenta miasta Poznania ds. smart city, oraz A. Maternę sekretarza grupy ds. smart city. 


\section{Wprowadzenie}

Obecnie większość miast to ośrodki wiedzy, które napędzają rozwój gospodarczy świata i przede wszystkim dlatego problematyka związana z rozwojem lokalnym stała się wysoce aktywną platformą badań i dyskusji.

Celem artykułu jest próba syntezy różnych podejść do definiowania inteligentnego miasta oraz wskazanie na ich wspólne cechy. Z kolei celem założonym w części empirycznej jest pokazanie stanu gotowości miasta Poznania do wdrażania rozwiązań typu smart city z perspektywy ich użytkowników. Podstawową tezą jest stwierdzenie, że koncepcja smart city jest silnie związana z postępem technologicznym i w miarę rozwoju technologii pojawiają się nowe obszary aktywności miast.

Pojęcie miasta inteligentnego może być różnorodnie definiowane, ponieważ każde miasto ma swoją specyfikę i możliwości wsparcia rozwoju w zakresie transportu ludzi i towarów, przeciwdziałania smogowi, przeciwdziałania zmianom klimatycznym i innych rozwiązań z dziedziny np. turystyki. W tak zarysowany obszar wpisują się w praktyce działania samorządu miasta Poznania.

Duża aktywność publikacyjna uwidacznia się w rosnącej liczbie artykułów. Dotyczy to zarówno czasopism polskich, jak i zagranicznych. W artykule dokonano przeglądu piśmiennictwa na temat smart city jako terminu funkcjonującego w tytułach prac naukowych, tworząc mapy pojęciowe. Analiza ujmuje zestawienie 5200 artykułów w bazie Web of Science z pięciu ostatnich lat, tzn. 2015-2019. Została ona przeprowadzona w programie VOSviewer (ver. 1.6.6). Minimalna liczba współwystąpień grupy wynosi 5. Wielkość etykiety oraz koła reprezentujących grupy tematyczne wskazuje na częstość występowania danej grupy tematycznej - im większa waga danej grupy tematycznej, tym większa etykieta i koło. Kolory zależą od klastra, do którego należy dana grupa tematyczna. Linie między kołami reprezentują powiązanie między grupami.

W wyniku analizy wyodrębniono dwa klastry tematyczne, które koncentrują się wokół zagadnień Internetu i rozwoju lokalnego (por. ryc. 1). Największa jest waga grupy tematycznej skupiającej się wokół Internetu (Samih 2019), Internetu Rzeczy, a w drugiej grupie nie ma tak dominujących tematów. Widać także silne powiązania pomiędzy grupami i pojawienie się nowych interdyscyplinarnych obszarów badań na przykład w zakresie ekonomii i sztucznej inteligencji lub IoT. Są to wysoce rozwojowe dziedziny badań, w których rozpiętość tematów jest bardzo duża. Warto zauważyć, że na styku tych dziedzin powstają z zasady najciekawsze, przełomowe prace.

Współczesne strategie rozwoju miast różnią się zasadniczo od tych sprzed kilkunastu lat przede wszystkim tym, że w dużym stopniu ukierunkowują rozwój jednostek na rozwiązania, które w charakterze swoim są kreatywne i inteligentne. Smart city uznawany jest za jeden z trzech następujących megatrendów zdefiniowanych do 2020 r. przez Frost i Sullivan (Gajewski i in. 2015):

- personalizacji informacji (connected living), wykorzystanie Internetu Rzeczy (IoT) do przepływu informacji, która ma służyć do szybkiej reakcji na zmie-

niające się potrzeby, pojawiające problemy, możliwe zagrożenia itd., 
- chmury dużych danych (big data clouds) (Dijkstra i in. 2015),

- inteligentnych miast.

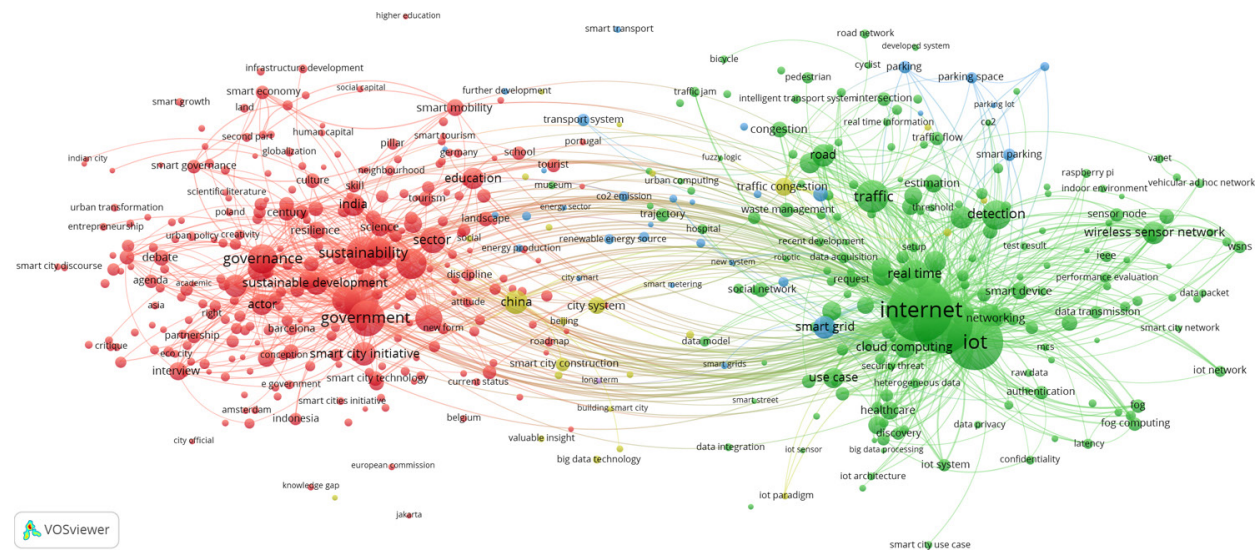

Ryc. 1. Klastry tematyczne wyodrębnione w obszarze poszukiwań publikacji w zakresie terminu smart city $\mathrm{w}$ bazie Web of Science

Źródło: opracowanie własne.

Innowacyjny rozwój miasta jest to proces wielowymiarowy, długotrwały, kosztowny, związany z wykorzystaniem różnych modeli biznesowych, istotny dla rozwoju z punktu widzenia konkurencyjności i atrakcyjności (Vence, Pereira 2018). Pomimo wzrostu zainteresowania problematyką nie ma uniwersalnej definicji inteligentnych miast. Należy jednocześnie zaznaczyć, że w literaturze spotykane są też inne określenia, które równolegle opisują te same trendy rozwoju. Do takich terminów należą: „miasto wiedzy”, "miasto cyfrowe” i „miasto ekologiczne", używane zamiennie w literaturze. Niemniej jednak coraz więcej osób próbuje rozwiązać problem nadmiernego uproszczenia koncepcji inteligentnego miasta, oferując całościowe, multidyscyplinarne perspektywy wokół kluczowych obszarów inteligentnej infrastruktury, gospodarki, mobilności, zarządzania, środowiska itd. (Yigitcanlar i in. 2015). W ramach systematycznych wysiłków różnych autorów zmierzających do wypracowania kompleksowej, wspólnej definicji inteligentnych miast (Anthopoulos, Series 2018) istnieje również tendencja do wysłuchiwania głosów ludzi $\mathrm{w}$ projektowaniu inteligentnych miast i procesach decyzyjnych, przejawiająca się zachęcaniem do bezpośredniego udziału lokalnych podmiotów $\mathrm{i}$ wielu zainteresowanych stron $\mathrm{w}$ planowaniu i realizacji działań społecznych, transformacji technologicznej i urbanistycznej dla inteligentnych miast. Istnieją jednak poważne pytania dotyczące tego, w jaki sposób to alternatywne podejście - udzielania głosu obywatelom $\mathrm{w}$ dyskursie na temat inteligentnego miasta - może zostać wdrożone w już zachodzących procesach rozwoju obszarów miejskich i przy wykorzystaniu dostępnych rozwiązań technologicznych (Pięta-Kanurska 2017). Mogłoby to następnie promować alternatywną wizję inteligentnych miast, w której brane pod uwagę są głosy obywateli - wizję, która nie jest zagrożona, ale możliwa do osiągnięcia. 
Stopień gotowości administracji miast i aktorów w ekosystemach miejskich do wdrażania rozwiązań smart city jest bardzo zróżnicowany i wymaga ciągłego monitorowania (Orłowski 2019). Przyjmując, że miasta są gotowe i otwarte na przyjęcie różnych rozwiązań technologicznych w globalnej ekonomii, stwarza to perspektywę przyjęcia bardzo dużego wachlarza możliwości, ze względu na różnorodność zasobów endogenicznych, egzogenicznych oraz szanse otwarcia nowych przestrzeni rozwojowych. Technologie mogą być pomocne w rozwiązywaniu różnych problemów rozwojowych, a także mogą przyczyniać się do podniesienia jakości życia mieszkańców lub ich satysfakcji z bycia mieszkańcem danej społeczności miejskiej. Koncepcja inteligentnego miasta w literaturze przedmiotu nie jest jednoznacznie zdefiniowana. Jak zauważa Korenik (2019), można znaleźć wspólny mianownik w definiowaniu innowacyjnego miasta, bo uważa się, że jest to miasto kreatywnie myślących mieszkańców (Pięta-Kanurska 2017), które potrafi rozwiązywać różne problemy przy użyciu nowoczesnych technologii, a ponadto korzystać z technologii informacyjno-komunikacyjnych (ICT). Definiowanie miasta inteligentnego jest też związane $z$ zrównoważonym rozwojem oraz ekonomią współdzielenia. Innowacyjne miasta stają się bardziej konkurencyjne w globalnej przestrzeni oraz osiągają wyższy stopień zaspokojenia potrzeb swoich mieszkańców, tzn. jakości życia. Należy podkreślić, że popularność koncepcji uwarunkowana jest wsparciem finansowym miast, np. poprzez dostępność środków publicznych na rozwój technologii energetycznych, oraz skłonnością globalnych korporacji (m.in. Cisco, Google i IBM) do znacznych inwestycji w projekty digitalizacji miast.

\section{Opis stanu wiedzy i analiza koncepcji smart city}

Jak podkreślono, koncepcja inteligentnego miasta jest bardzo różnorodnie definiowana i często możemy się spotkać z jej krytyką. Dyskurs w obszarze tej problematyki koncentruje się na tym, co określa się mianem „inteligentnych miast korporacyjnych". Termin inteligentne miasto powstał w Stanach Zjednoczonych w dwóch globalnych korporacjach zaawansowanych technologii, IBM i Cisco. Wskazuje to na punkt widzenia, w którym połączenie chęci zysku dla globalnych korporacji z jednej strony i przedsiębiorczego zarządzania $z$ drugiej strony, napędza wiodącą narrację o inteligentnym mieście. Głosy krytyki padają w pod adresem nowych inteligentnych miast budowanych od podstaw w Azji, świecie arabskim, a nawet w Europie, kierowanym przez gigantyczne korporacje (np. Cisco, IBM i Siemens), np. takich jak Masdar w Zjednoczonych Emiratach Arabskich (ZEA), Songdo w Korei Południowej i PlanIT Valley w Portugalii. Podstawowym założeniem dotyczącym tych miast - co jest mocno kwestionowane w literaturze przedmiotu - jest to, że IT może automatycznie sprawić, by miasta były lepiej prosperujące gospodarczo i równe, wydajniej zarządzane i mniej rozrzutne pod względem środowiskowym - z niewielką przestrzenią dla zwykłych ludzi i problemów wykluczenia społecznego. Korporacyjna wizja inteligentnych miast promuje trend w kierunku „otwartości na biznes” i coraz częściej stają się one tłem dla 
reklamy korporacyjnej i prywatyzacji przestrzeni publicznej. Sytuacja ta wydaje się szczególnie niebezpieczna w krajach rozwijających się oraz postkomunistycznych, liczących na szybki efekt w postaci konwergencji gospodarczej związanej ze zmianami technologicznymi. Ten brak zainteresowania demokratycznym procesem decyzyjnym ze strony innowatorów oraz faktyczne zaangażowanie i uczestnictwo obywateli zachęciły autorów do poszukiwania alternatywnej wersji inteligentnych miast i zapewnienia kontrapunktu wizji korporacyjnej. Ta alternatywna wizja wyłoniła się z małych i raczkujących przykładów inteligentnych inicjatyw opartych na uczestnictwie w społeczności.

Koncepcja smart city charakteryzuje się następującymi ważnymi cechami:

- nie jest ograniczona do konkretnych terytoriów;

- nie jest też sprecyzowana pod względem wielkości miasta, ale częściej odnosi się do miast globalnych, ze względu na środowisko korzystne do rozwoju inteligentnych rozwiązań;

- nie jest sprecyzowana co do wachlarza rozwiązań proponowanych w poszczególnych ośrodkach, np. e-administracja, inteligentny transport, usługi miejskie, otwarte dane $w$ miastach i wiele innych;

- nie jest też określona w zakresie rozmiarów projektów, które są bardzo zróżnicowane (do dużych projektów należy zaliczyć Barcelonę), całe miasto obejmują projekt iN2015 (inteligentny kraj) w Singapurze, Songdo w Korei Południowej, miasto wiedzy w Guangzhou w Chinach, miasto Masdar w Zjednoczonych Emiratach Arabskich);

- źródła finansowania inicjatyw służących wspieraniu smart city są różnorodne, np. Unia Europejska (UE) podejmuje stałe wysiłki na rzecz wspierania inicjatyw inteligentnych miast - inwestując miliony euro w projekty badawcze, rozwojowe i pionierskie, które próbują połączyć inicjatywy inteligentnego miasta z celami środowiskowymi (takimi jak ograniczenie emisji gazów cieplarnianych) i rozwojem gospodarczym (Alizadeh 2018).

Aby dobrze zrozumieć istotę różnych koncepcji inteligentnego miasta warto skupić się na tym, co je łączy. Pierwszą z takich wspólnych cech jest opieranie filozofii smart city na występowaniu procesów innowacyjnych, które mogą przybierać różne formy: produktowe, organizacyjne, procesowe, marketingowe. Procesy, o których mowa, przechodzą przez podstawowe etapy: inwencja (pomysł), innowacja (zastosowanie) oraz dyfuzja (Korenik 2019). Aktorzy biorą udział w różnych etapach rozwoju projektów. Aby zilustrować takie procesy, można przytoczyć ciekawy przykład z Amsterdamu (Anthopoulos 2019). Miasto to próbowało sformalizować status smart city już w 2009 r., ustanawiając organizację partnerską Amsterdam Smart City (ASC), w skład której wchodzą przedsiębiorstwa, społeczne grupy badawcze, instytucje wiedzy i instytucje samorządowe, które współpracują nad projektami inteligentnego miasta. ASC opiera się na koncepcji miejskiego żywego laboratorium, która opisuje zorientowaną na użytkownika otwartą strukturę innowacji i angażuje użytkowników jako aktywnych uczestników procesu innowacji (Anthopoulos 2019).

W świecie, w którym liczba ludności stale rośnie, znacząco napędzając konsumpcję powodującą niedobory zasobów i zmiany klimatyczne, epidemie, 
motywacja do innowacyjnych rozwiązań jest niezwykle istotna. W szczególności obszary miejskie są odpowiedzialne za większą część zużycia zasobów, powodując rosnącą potrzebę tworzenia inteligentniejszych infrastruktur w poszukiwaniu bardziej ekologicznej i energooszczędnej gospodarki miejskiej (Hancke i in. 2013). Postęp jest widoczny zarówno od strony praktycznej, jak i teoretycznej. Aktualnie w zakresie zainteresowania regionalistów związanych z nowymi technologiami na pierwszym miejscu wymienia się inteligentne miasta (Markowski 2016). Kolejne to: duże bazy danych, łączność i konwergencja (ang. connectivity \& convergence, connected living), sztuczna inteligencja, automatyzacja i robotyka (ang. artificial intelligence, automation, robotics), urbanizacja, rosnąca liczba ludności na świecie (ang. global population growth), starzejące się społeczeństwo (ang. ageing population), zrównoważony rozwój (ang. sustainability), wyczerpywanie się zasobów naturalnych (ang. resource scarcity), odnawialne źródła energii (ang. renewable energy), globalizacja, ekonomia dzielenia się (ang. sharing economy).

Drugą ważną wspólną cechą jest oparcie koncepcji na roli wiedzy. Koncepcje inteligentnych miast korzystają ze wszystkich możliwych rodzajów wiedzy, która jest kluczowa dla rozwoju procesów technologicznych, społecznych i gospodarczych. Wiedza jest ściśle powiązana $z$ instytucjami funkcjonującymi na danym terytorium i zdecydowaną przewagę mają miasta o ugruntowanej pozycji gospodarczej z licznymi instytucjami działającymi na rzecz nauki i wiedzy. Szczególnie w przypadku koncepcji smart city podkreśla się rolę wiedzy technologicznej, która umożliwia rozwój i absorpcję nowoczesnych technologii. Głównym impulsem do rozwoju miast jest obecnie rozwój nowych technologii chmurowych stosowanych $w$ miejskich systemach monitorowania. Potencjał integracji chmury i czujników $\mathrm{w}$ inteligentnych miastach zapewnia możliwość uzyskania dowolnego rodzaju danych. Analiza gigadanych to dziedzina badań, w której wielka skala opisu zjawisk masowych jest konieczna do odkrycia nowej wiedzy, której nie można odkryć $\mathrm{w}$ małej skali i która pozwala na partycypację $\mathrm{w}$ przyszłości (Cellary 2019). Bardzo ważne w kwestii zarządzania publicznego jest zbieranie danych i informacji przez sensory i sieci sensorów. Dzięki takiemu podejściu decyzje podejmowane na poziomie gminy mogą być bardziej racjonalne w efekcie bogactwa wiedzy i informacji. Wiedza jest także rozwijana $w$ ośrodkach akademickich i w instytucjach. W tych procesach biorą udział też firmy, które rozwijają swoje ośrodki B+R.

Trzecią cechą wspólna dla różnych koncepcji jest inteligentne zrównoważenie. Choć badania potwierdzają, że środowisko i zrównoważony rozwój odgrywają w innowacyjnych miastach marginalną rolę (Joss i in. 2018), widać wyraźnie, że istnieją przypadki miast, gdzie środowisko naturalne i zrównoważony rozwój stawiane są na pierwszym miejscu, np. Wiedeń, Vancouver, Kopenhaga. Wiedeń promuje zrównoważony rozwój i ochronę zasobów poprzez kluczowe strategie wizję zrównoważonej przyszłości Wiednia w 2050 r. oraz plan działania na rzecz efektywnego energetycznie i przyjaznego dla klimatu rozwoju obszarów miejskich do 2020 r. Dla zrównoważonego rozwoju inteligentnego miasta Wiednia ważne jest ustanowienie równowagi między efektywnym wykorzystaniem zasobów, jakością życia i innowacjami (Anthopoulos 2019). 
Czwartą cechą koncepcji smart city jest ukierunkowanie się na konkurencyjność. Jest to jeden z kluczowych elementów strategii rozwoju każdego miasta inteligentnego. Może ona być rozumiana jako konkurencyjność miasta poprzez wdrożenie smart city oraz konkurencyjność poszczególnych projektów. Zwłaszcza w przypadku konkurencyjności gospodarczej duże znaczenie ma ewolucyjny charakter koncepcji, który oznacza w praktyce coraz większą konkurencyjność w miarę postępu technologicznego. Ważna jest w tym przypadku rola i aktywność miasta w sferze aktywnego wsparcia biznesu i współpracy z biznesem w celu budowania rozwiązań podnoszących konkurencyjność danych ośrodków. Na konkurencyjność miasta mają wpływ: poziom kapitału ludzkiego, stopień zdolności innowacyjnych oraz jakość lokalnej infrastruktury. Konkurencyjność miasta jest uzależniona od: zdolności miast do przyciągania kreatywnych i innowacyjnych ludzi lub zapewnienia wysokiej jakości obiektów kulturalnych (Kitson i in. 2004). Innymi słowy, konkurencyjność w coraz większym stopniu dotyczy kreatywności, wiedzy i warunków środowiskowych, a nie opiera się wyłącznie na nagromadzonym bogactwie (Huggins 2003). Czynnikiem wpływającym na konkurencyjność jest wzrost wiedzy i kreatywności indukowany poprzez np. klastry (Porter 1998) lub sieci (Huggins, Izushi 2007) firm i innych instytucji z otoczenia biznesu. Z nowych trendów, widoczne są silne tendencje do skupiania się smartproduktów i usług w bogatszych miejscach, tworzą się tzw. huby innowacji (Pięta-Kanurska 2018).

Polaryzacja wśród innowacyjnych miast jest także dość istotnie zauważalna, co zostało wcześniej podkreślone. W kontekście budowania sieci na arenie międzynarodowej zdecydowanie lepszy potencjał mają miasta światowe. W tej globalnej strukturze sieci miasta światowe są zazwyczaj postrzegane jako pionierzy. Tak jest w przypadku Nowego Jorku lub Londynu. Ambicja inteligentnego miasta jest jednoznacznie związana $z$ globalną siecią. Intersujące jest także podejście tych miast sugerujące innym miastom współpracę np. z Barceloną, Kopenhagą, czy Amsterdamem, aby dzielić się doświadczeniami i rozwijać projekty „latarni”, które zademonstrują nowe podejścia w skali całego globu. Serce innowacyjnych miast tworzą miasta stołeczne lub alfa-światowe. Są one postrzegane jako modele do naśladowania przez inne miasta krajowe i regionalne. Ponadto obraz pokazuje, że innowacje $\mathrm{w}$ inteligentnych miastach są zasadniczo ściśle wspierane politycznymi działaniami i globalnymi aspiracjami miast (Joss i in. 2018).

Duże znaczenie jakości kapitału ludzkiego mającego wpływ na rozwój miasta i jako konsument innowacyjnych rozwiązań to kolejna ważna cecha. Dla rozwoju innowacyjnego miasta istotna jest klasa kreatywna, której członkowie generują więcej pomysłów i z większym prawdopodobieństwem można przypuszczać, że założą nowe innowacyjne firmy, które z pewnością będą generować różne ciekawe rozwiązania dla innowacyjnych miast. Szczególnie ważne dla rozwoju miasta są takie zawody, jak: inżynierowie, naukowcy, architekci, artyści, bo ich działanie wiąże się z powstawaniem nowych usług, produktów i często generowaniem innowacyjnych procesów.

Miasto innowacyjne powinno także tworzyć klimat przyjazny dla mieszkańców. Bardzo ciekawe podejście prezentuje Dariusz Stasiak (https://dariuszstasik. com), który miasta inteligentne definiuje jako „miasta szczęśliwe”, za Charlesem 
Montgomerym, twórcą słynnej książki „Miasto szczęśliwe”. Koncepcja ta opiera się na trzech komponentach: zdrowia, produktywności, rozwoju osobistego. Pierwszy komponent wytycza działania np. na rzecz poprawy czystości powietrza, poprawy bezpieczeństwa, opieki medycznej, sztuki, kultury, edukacji, bezpieczeństwa. Do rozwiązań, które mogą mieścić się w tym obszarze, zaliczyć można na przykład: aplikacje informujące o zagrożeniach wynikających ze smogu, wykorzystanie dronów do przewozu leków i in. Drugi komponent dotyczy przedsiębiorczości, która rozumiana jest poprzez inteligentne rozwiązania $\mathrm{w}$ następujących obszarach, takich jak: szeroko rozumiana komunikacja dynamic traffic solution, centralne aplikacje miejskie car pooling, rent bike\&car, bird life zone, date acess, sprawy urzędowe, parking mobile payment, changing rooms, smart buiding, rozwiązania dla niepełnosprawnych itd. Ostatnim komponenten miasta szczęśliwego jest rozwój osobisty. Rozumiany jest on poprzez rozwiązania technologiczne w dziedzinie: stref przemysłowych, stref biznesowych, wsparcia dla nowych biznesów i startupów, szerokiej oferty szkolnictwa oraz uczelni, wsparcia procesów rekrutacyjnych, szkoleń zawodowych i językowych, atrakcyjności środowiska itd. Autor tego podejścia uważa, że w ramach tych trzech obszarów mieszczą się wszystkie ważne kwestie mogące uczynić społeczeństwo szczęśliwym.

\section{Miasto Poznań na drodze do smart city}

Zwiększanie atrakcyjności miasta Poznania jako smart city otwiera przed nim wiele „nowych przestrzeni możliwości rozwojowych”. Poznań, dzięki kreatywnemu zachowaniu swoich rodzimych aktorów, może osiągnąć szczególne cele, które mogą być wspieranie przez nowe technologie i z pewnością zwiększą efektywność gospodarczą, pozwolą na odkrywanie nowych ścieżek rozwojowych, lepszą komunikację z mieszkańcami itp. Ponieważ proces rozwoju innowacyjnych rozwiązań na terenie miasta Poznania jest w początkowej fazie rozwoju, autorka wykonała badania na próbie 2000 studentów z Poznania w 2020 r., które miały pokazać stopień wykorzystania IoT w Poznaniu. Celem badania było także zindentyfikowanie, czy rzeczywiście smart city jest identyfikowane przez studentów poprzez aplikacje IoT i czy pomagają im one w codziennym funkcjonowaniu. Z badań wynika, że studenci w małym stopniu identyfikują obszary kluczowe dla smart city. Uważają, że głównie aplikacje społecznościowe są im pomocne w zdobywaniu wiedzy i informacji o mieście. Aplikacje dedykowane rozwojowi smart city w niewielkim stopniu są wykorzystywane przez studentów. Jak widać na rycinie 2, preferencje studentów z poszczególnych poznańskich uczelni są podobne, ale jednak można zauważyć, że na czoło wysuwają się aplikacje społecznościowe.

Biorąc pod uwagę współczesne działania, miasto Poznań zindywidualizowało swoje podejście do rozwoju, przyjmując następującą definicję: ,jest to rozwinięty obszar miejski, który tworzy warunki dla trwałego rozwoju gospodarczego i wysokiej jakości życia poprzez doskonalenie w wielu kluczowych obszarach. $\mathrm{Za}$ ich doskonalenie odpowiedzialne są takie elementy, jak: silny kapitał ludzki, kapitał społeczny i/lub infrastruktura teleinformatyczna. «Smart city Poznań» 

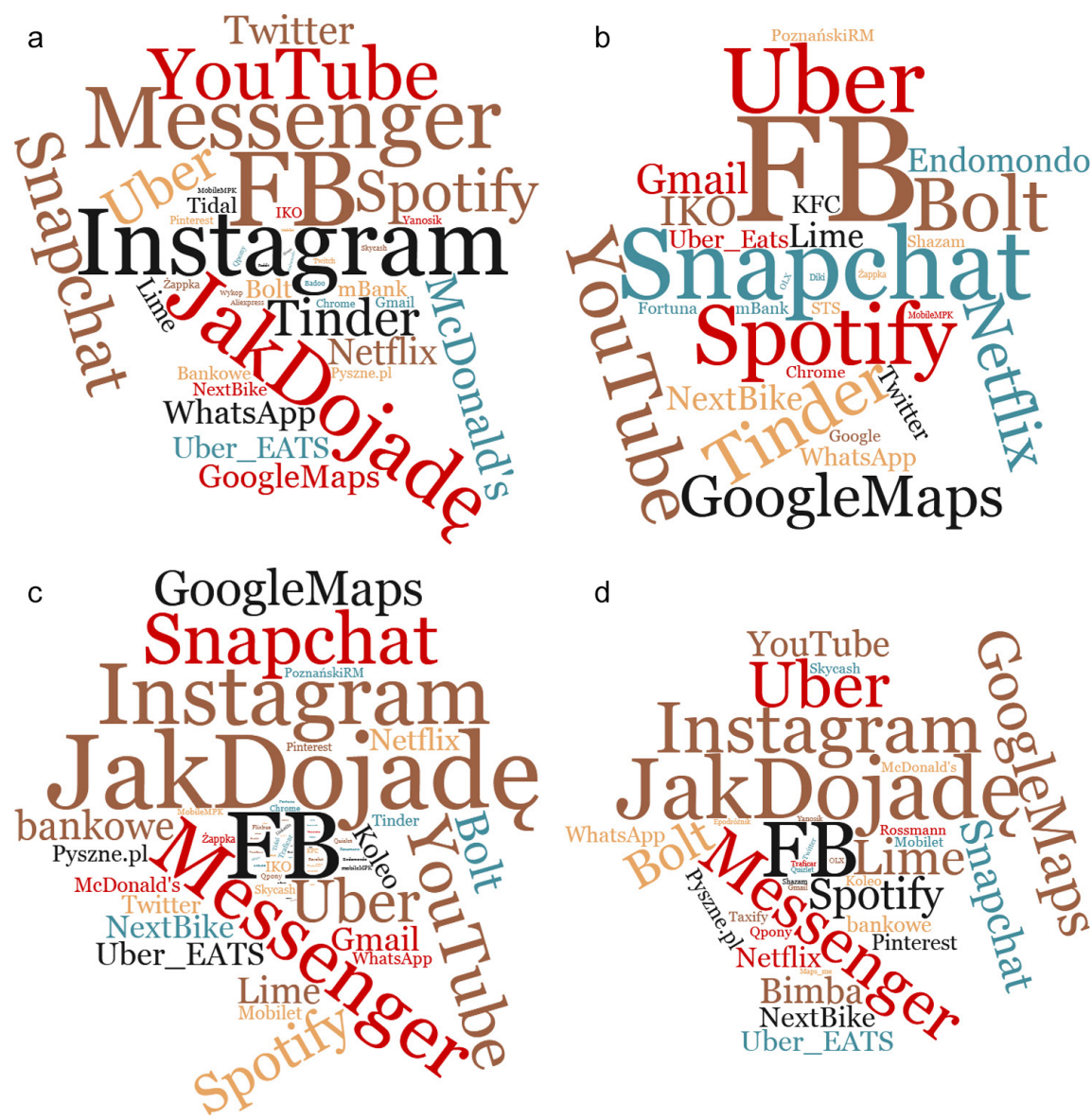

Ryc. 2. Postrzeganie aplikacji związanych ze smart city przez studentów poznańskich uczelni: a - Politechnika Poznańska, b - Uniwersytet im. Adama Mickiewicza, c - Uniwersytet Ekonomiczny, d - Uniwersytet Medyczny

Źródło: opracowanie własne na podstawie badań ankietowych na grupie 2000 studentów w Poznaniu wykonane w $2020 \mathrm{r}$.

to dobrze funkcjonujące przyszłościowe miasto, oparte na aktywnym działaniu świadomych, niezależnych i decydujących o swoich losach obywateli”. Koncepcja ta powstała w oparciu o perspektywę doświadczeń innych miast europejskich, których definicje są bardzo różnorodne i koncentrują się na pewnych słowach kluczowych, które warto przeanalizować. Patrząc na owocne rezultaty wdrażania innowacyjnych koncepcji rozwoju miast, wzorowano się na doświadczeniach liderów w zakresie różnych rozwiązań. Definicja miasta inteligentnego Barcelony jest bardzo syntetyczna i dobrze ujmująca istotę innowacyjnej gospodarki, koncentrując uwagę na "przepływie i integracji danych w różnych dziedzinach”.

Inną definicję przyjmuje Sztokholm, który zakłada, że inteligentne miasto to po prostu takie miasto, które wykorzystuje cyfryzację i nowe technologie w celu uproszczenia i poprawy życia swoich mieszkańców, przedsiębiorców 
oraz odwiedzających. Jak widać z przytoczonej definicji, pojawia się w tym ujęciu nowa wartość dodana do poprzedniej koncepcji: w postaci poprawy życia mieszkańców, przedsiębiorców i turystów. Ciekawa z punktu widzenia oryginalnego charakteru, jest definicja przyjęta przez Kopenhagę, w której podkreśla się, że miasto to „żywe laboratorium” do testowania inteligentnych technologii w celu sprostania wyzwaniom urbanizacji i zmian klimatycznych. W tej definicji podkreślono najważniejsze problemy miasta i chęć ich rozwiązania poprzez technologie przyjazne mieszkańcom i przedsiębiorcom. Te problemy możemy rozumieć także z perspektywy barier rozwojowych.

W literaturze i rankingach dość często mówi się o Wiedniu jako mieście wzorcowym w obszarze zastosowania inteligentnych rozwiązań. Celem Smart City Wien jest osiągnięcie najlepszej jakości życia wszystkich mieszkańców, przy jednoczesnym zminimalizowaniu zużycia zasobów poprzez zastosowanie nowoczesnych technologii. W tej definicji zauważalny jest element dbałości o zrównoważony rozwój. Podobnie Berlin idzie ścieżką rozumowania, że wykorzystanie technologii teleinformatycznych musi się przyczynić do opracowania konkretnych rozwiązań, które uczynią miasto bardziej wydajnym, zdrowszym, bardziej zrównoważonym, łatwiejszym do życia i czystszym.

Według międzynarodowego rankingu „Quality of Living” od 9 lat liderem wśród miast jest (https://www.mercer.com/newsroom/2019-quality-of-living-survey.html) Wiedeń, za którym uplasowały się w 2019 r.: Zurych, Auckland w Nowej Zelandii, Monachium, Vancouver, Düsseldorf i Frankfurt, Genewa, Kopenhaga i Bazylea. W tym rankingu brane są pod uwagę m.in.: sytuacja polityczna, poziom oświaty, transportu, opieki medycznej, środowisko naturalne oraz zasoby mieszkaniowe. Jest to jedna z pomocnych płaszczyzn, dzięki której możliwe jest porównanie jakości życia w poszczególnych metropoliach.

Zaprezentowana w artykule koncepcja smart city Poznań wpisuje się w założenia strategii rozwoju miasta Poznania 2020+, w tym w realizację priorytetów: 1) nowoczesna przedsiębiorczość, 2) zielone mobilne miasto, 3) przyjazne osiedla, 4) silna metropolia, 5) wspólnotowość i dialog społeczny. Miasto podejmuje szereg ciekawych inicjatyw kreowania nowoczesnej przedsiębiorczości, wśród których można wymienić: działania Biura Obsługi Inwestorów, które skutecznie wspiera sektor IT oraz dbałość o czyste środowisko. Priorytetem dla rozwoju miasta Poznania jest poprawa mobilności i bezpieczeństwa. Opracowano koncepcję wsparcia bezpieczeństwa i dostępności dróg pieszych, rowerowych i transportu publicznego oraz potrzeb osób zmotoryzowanych na terenie Poznania, a także ulepszenia obecnej polityki parkingowej, w tym kontynuacji rozwoju parkingów typu „parkuj i jedź”. W zakresie bezpiecznych osiedli należy wspomnieć o rozbudowie monitoringu miejskiego. W Systemie Monitoringu Wizyjnego Miasta Poznania funkcjonuje 735 kamer, w tym 334 obrotowe, 383 stacjonarne i 18 panoramicznych, dzięki którym przestępczość $\mathrm{w}$ tych miejscach spadła o kilkadziesiąt procent. Rozwiązania te pomagają też policji i straży miejskiej $\mathrm{w}$ dochodzeniu sprawców wykroczeń i przestępstw.

Prognozuje się, że główną siłą prowadzącą do radykalnych przemian w miastach przyszłości będzie Internet Rzeczy (IoT - Internet of Things) i Usług (IoS 
- Internet of Services), a najważniejszą rolę zaczną odgrywać miniaturowe i wszechobecne urządzenia, świadczące usługi dla obywateli w trybie JIT (ang. Just in Time) i JIP (ang. Just in Place), czyli w każdym miejscu, czasie i sytuacji. Poznań w partnerstwie $\mathrm{z}$ różnymi podmiotami oferuje mieszkańcom szeroką partycypację społeczną oraz możliwości korzystania z różnego rodzaju usług.

Silna metropolia to lepsze zarządzanie, koordynacja i integracja działań. Przykładem może być Model Poznania 3D - rozwiązanie nowoczesne i innowacyjne w skali kraju wspomaga działania w zakresie planowania i zagospodarowania przestrzennego, podejmowania decyzji dotyczących gospodarki nieruchomościami czy bezpieczeństwa publicznego. Wspiera konsultacje społeczne związane z gospodarką przestrzenną, ochroną środowiska i rewitalizacją, a także wzbogaca oferty dla inwestorów.

\section{Podsumowanie}

Z podsumowania rozważań wynikają następujące wnioski:

1. Nie ma jednej uniwersalnej koncepcji, która byłaby uznana za wzorcową przy podejmowaniu różnych decyzji strategicznych w miastach czy na polu tereoretycznym.

2. Do wspólnych cech wszystkich koncepcji należy zaliczyć: występowanie procesów innowacyjnych, oparcie koncepcji na roli wiedzy, inteligentne zrównoważenie, ukierunkowanie na konkurencyjność oraz jakość kapitału ludzkiego.

3. Koncepcje ewoluują w miarę postępu technologicznego, co pozwala na znacznie szersze potraktowanie obszarów smart city.

4. Współwystępowanie w literaturze szeregu podobnych koncepcji, które uznać należy za pokrewne. Są to np. „information city” (Castells 1996), „intelligent city” (Komninos 2002), „knowledge city” (Carrillo 2008) czy też „digital city” (Yovanof, Hazapis 2009).

5. Widać wyraźnie, że koncepcja smart city coraz częściej jest brana pod uwagę przy planowaniu strategicznym w miastach. Miasta wypracowują własne dopasowanie i specyficzne dla swoich problemów rozwojowych i własnego potencjału rozwiązania technologiczne. Bardzo ważne, według autorki tekstu, jest wypracowanie optymalnych rozwiązań, wykorzystujących przestrzenie szans, jakie istnieją w czterech obszarach: wiedzy, kapitale ludzkim, „inteligentnym zrównoważeniu" i konkurencyjności.

6. Istotnym czynnikiem stymulującym zachodzące zmiany w kierunku rozwoju inteligentnych miast jest proces „uczenia się”, który powinien być stymulowany poprzez różnego rodzaju akcje miast informujące o nowych rozwiązaniach technologicznych i włączające społeczności miast w te procesy. Jak pokazują badania własne autorki tekstu, wiedza na ten temat wśród młodych ludzi nie jest rozwinięta. 


\section{Literatura}

Alizadeh T. 2018. Crowdsourced Smart Cities versus Corporate Smart Cities. IOP Conference Series: Earth and Environmental Science, 158. Institute of Physics Publishing (https://doi.org/ 10.1088/1755-1315/158/1/012046).

Anthopoulos L. 2019). Smart City Emergence. Cases From Around the World. Elsevier.

Anthopoulos L.G., Series I.T. 2018. The Rise of the Smart City. 2. The rise of the Smart City (https:// doi.org/10.1007/978-3-319-57015-0).

Carrillo FJ. i in. 2008. Rising knowledge cities: the role of urban knowledge precincts. Journal of Knowledge Management, 12(5): 8-20.

Castells M. 1996. The rise of the network society: The information age. Economy, Society, and Culture, 1.

Cellary W. 2019. Współczesny obieg danych (c).

de Falco S., Angelidou M., Addie J.P.D. 2019. From the "smart city" to the "smart metropolis"? Building resilience in the urban periphery. European Urban and Regional Studies, 26(2): 205-223 (https://doi.org/10.1177/0969776418783813).

Dijkstra L., Garcilazo E., McCann P. 2015. The effects of the global financial crisis on European regions and cities. Journal of Economic Geography, 15(5): 935-949 (https://doi.org/10.1093/jeg/ lbv032).

Gajewski J., Paprocki W., Pieriegud J. 2015. Megatrendy i ich wpływ na rozwój sektorów infrastrukturalnych.

Hancke G.P., de Silva B., Hancke G.P. 2013. The role of advanced sensing in smart cities. Sensors (Switzerland) (t. 13) (https://doi.org/10.3390/s130100393).

Huggins R. 2003. Creating a UK competitiveness index: regional and local benchmarking. Regional Studies, 37(1): 89-96 (https://doi.org/https://doi.org/10.1080/0034340022000033420).

Joss S., Sengers F., Schraven D., Caprotti F., Dayot Y., Joss S., Dayot Y. 2018. The Smart City as Global Discourse: Storylines and Critical Junctures across 27 Cities (February 2019) (https://doi.org/1 0.1080/10630732.2018.1558387).

Kitson M., Martin R., Tyler P. 2004. Regional competitiveness: An elusive yet key concept? Regional Studies, 38 (https://doi.org/https://doi.org/10.1080/0034340042000320816).

Komninos N. 2002. Intelligent cities: innovation, knowledge systems, and digital spaces. Taylor \& Francis.

Korenik A. 2019. Smart Cities - miasta inteligentne w Europie i Azji. CeDeWu, Warszawa.

Pięta-Kanurska M. 2017. Wehikuły rozwoju współczesnych miast. Wyzwania dla Wrocławia. Studia KPZK PAN, 177: 185-188 (https://doi.org/DOI: 10.24425/118581).

Pięta-Kanurska M. 2018. Wprowadzenie. Medycyna nowożytna: studia nad historia medycyny. Polska Akademia Nauk, Instytut Historii Nauki.

Mora L., Deakin M. 2019. Smart city development in Europe. Untangling Smart Cities, (July): 135170 (https://doi.org/10.1016/b978-0-12-815477-9.00005-0).

Mora L., Deakin M., Reid A. 2019. Strategic principles for smart city development: A multiple case study analysis of European best practices. Technological Forecasting and Social Change, (July) 142: 70-97 (https://doi.org/10.1016/j.techfore.2018.07.035).

Moustaka V., Vakali A., Anthopoulos L.G. 2018. A Systematic Review for Smart City Data Analytics (March 2019) (https://doi.org/10.1145/3239566).

Orłowski A. 2019. Model gotowości procesowej urzędu miejskiego dojścia do smart city. CeDeWu, Warszawa

Porter M.E. 1998. Clusters and the new economics of competition. Harvard Business Review, 76(6): 77-90.

Samih H. 2019. Smart cities and internet of things. Journal of Information Technology Case and Application Research, 21(1): 3-12 (https://doi.org/10.1080/15228053.2019.1587572).

Vence X., PereiraÁ. 2018. Eco-innovation and Circular Business Models as drivers for a circular economy. Contaduría y Administración, 64(1): 64 (https://doi.org/10.22201/fca.24488410e.2019.1806).

Yigitcanlar T., Inkinen T., Makkonen T. 2015. Does Size Matter? Knowledge-Based Development of Second-Order City-Regions in Finland. Disp, 51(3): 62-77 (https://doi.org/10.1080/02513625. 2015.1093352). 
Yovanof G., Hazapis G. 2009. An Architectural Framework and Enabling Wireless Technologies for Digital Cities \& Intelligent Urban Environments. Wireless Personal Communications, 49(3): 445-463.

\title{
The essence of the concept of a smart city. The activity of the city of Poznań leading to a smart city
}

\begin{abstract}
Cities are not equally prepared to adopt the solutions characteristic for a smart city. This problem was analysed by the author and the results were presented in the empirical part of the article on the basis of the city of Poznan. Various factors have the impact on the variety and dynamics in the process of formulating concepts of a smart city and therefore they make it an interesting area of study. The aim of this article is the attempt to sum up different attitudes to defining a smart city and to indicate their common features. The aim of the empirical part is, however, to present the preparedness of the city of Poznań to adopt the solutions as a smart city. The main thesis of this article is the statement that the concept of a smart city is strongly connected with the technological progress and as technologies develop, new areas of activities of the city appear and can be implemented.
\end{abstract}

Key words: smart city, IoT, Geography of Innovation Sustainability, territorial capital, regional economy, competitiveness, Poznań 